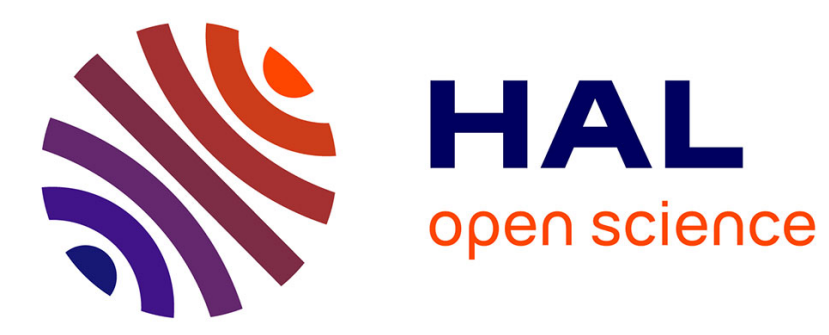

\title{
Democracy and Voting
}

Annabelle Lever

\section{To cite this version:}

Annabelle Lever. Democracy and Voting: A Response to Lisa Hill. British Journal of Political Science, 2010, 40 (4), pp.925 - 929. 10.1017/S0007123410000177. hal-02506507

\section{HAL Id: hal-02506507 https://hal-sciencespo.archives-ouvertes.fr/hal-02506507}

Submitted on 12 Mar 2020

HAL is a multi-disciplinary open access archive for the deposit and dissemination of scientific research documents, whether they are published or not. The documents may come from teaching and research institutions in France or abroad, or from public or private research centers.
L'archive ouverte pluridisciplinaire HAL, est destinée au dépôt et à la diffusion de documents scientifiques de niveau recherche, publiés ou non, émanant des établissements d'enseignement et de recherche français ou étrangers, des laboratoires publics ou privés. 


\title{
Democracy and Voting: A response to Lisa Hill
}

\author{
Annabelle Lever \\ Annabelle.lever@manchester.ac.uk
}

BRITISH JOURNAL OF POLITICAL SCIENCE, 40.4, Autumn 2010, 925-929.

Lisa Hill's response to my critique of compulsory voting, like similar responses in print or in discussion, ${ }^{1}$ remind me how much a child of the '70s I am, and how far my beliefs and intuitions about politics have been shaped by the electoral conflicts, social movements and violence of that period.

But my perceptions of politics have also been profoundly shaped by my teachers, and fellow graduate students, at MIT. Theda Skocpol famously urged political scientists to 'bring the state back in' to their analyses, ${ }^{2}$ and to recognise that political identities, interests and coalitions cannot be read off straightforwardly from people's socio-economic position. In their different ways, this was the lesson that Suzanne Berger, Charles Sabel and Joshua Cohen tried to teach us, emphasising the ways that political participation and conflict, themselves, can change people's identities, their sense of what it is desirable and possible, and their ability to recognise, or oppose, the freedom and equality of others. ${ }^{3}$

I do not therefore take it as self-evident that the poor and seemingly powerless should be politically apathetic, unwilling to vote, or incapable of imagining a political

\footnotetext{
${ }^{1}$ For the debate on compulsory voting in Politics see Justine Lacroix, 'A Liberal Defence of Compulsory Voting', Politics 27 (3) 2007, pp. 190-95; A. Lever, “ “A Liberal Defence of Compulsory Voting": Some Reasons for Scepticism', Politics, 28 (1), 2008, pp. 61-64; Bart Engelen, 'Why Liberals Can Favour Compulsory Attendance', Politics 29 (3), 2009, pp. 218-222 and A. Lever, 'Liberalism, Democracy and the Ethics of Voting', Politics 29.(3) 2009, pp. 223 - 227.

${ }^{2}$ Theda Skocpol, 'Bringing the State Back In: Strategies of Analysis in Current Research', in Peter B. Evans, Dietrich Rueschemeyer and Theda Skocpol, eds. Bringing the State Back In, (Cambridge University Press, 1985), pp. 3-43

${ }^{3}$ Suzanne Berger, ed., Organizing Interests in Western Europe, (Cambridge University Press, 1983); Charles F. Sabel, Work and Politics: The Division of Labour in Industry (Cambridge University Press, 1984), and Joshua Cohen, Philosophy, Politics, Democracy: Selected Essays, (Harvard University Press, 2009). See also Archon Fung's Empowered Participation: Reinventing Urban Democracy, (Princeton University Press, 2004).
} 
solution to at least some of the problems confronting them. Nor do I suppose that non-voters are all-of-a-piece, and that their shared interests are, inevitably, more significant, morally or politically, than those which divide them. Such assumptions seem mistaken in the case of voters, and I see no reason why they should be true of non-voters. The people we find in these categories are not predestined to be in one rather than the other; they do not always stay where they start off; and at an individual level, the reasons why people fall into one group, rather than another, are likely to be complex and sometimes unpredictable. ${ }^{4}$

Above all I see nothing in a commitment to democratic government, understood realistically or in more idealistic terms, that requires us to treat raising turnout at national elections (once every four years or so) as of such moral or political importance that we should make it legally mandatory. Realistically, it is an open question how far the ballot box is, for most people, the path to empowerment important though it is that people should have an equal right to vote and to stand as candidates at national elections. On a more idealistic view of democratic politics it is hard to avoid the thought that the importance of national elections to selfgovernment, posited by proponents of compulsory voting, reflects an alienated and alienating view of democracy, in which the choice of our leaders becomes more important than the development and exercise of our own capacities to lead; and in which our awe at the power our leaders might wield is matched only by our inability to imagine less intimidating, distant and centralised forms of politics.

But before saying a little more about these points, and their significance for compulsory voting, I would like to dispel some misunderstandings or misrepresentations of my views in Hill's essay. I do not believe socio-economic disparities in turnout are not worrying for democratic politics, nor do I believe that

\footnotetext{
${ }^{4}$ Sometimes, religion makes one politically apathetic; sometimes it arouses one to indignant action against both religious and political authorities, as we see with the recent furors over sex abuse in the Catholic Church in the USA, Ireland, Germany and Italy. Sometimes being a woman means that electoral politics seems irrelevant, or a man's business, and at others, the fact that it is dominated by men seems a decisive reason for action. The best example of the latter might be Emily's List, and the fury, rather than resignation, generated by the treatment of Anita Hill during the televised hearings of the Judiciary Committee of the US Senate on Clarence Thomas.
} 
abstention is generally synonymous with consent. I do not assume that people have a right not to vote, but try to explain why moral and legal rights to abstain are an important part of democratic politics, including electoral politics.

Inequalities in turnout are worrying, because they suggest a vicious cycle in which those who are doing least well in our societies are least likely to vote, and are therefore least likely to get favourable attention from politicians eager to get elected or re-elected. (pp. 4- 5; 8) Moreover, as I explain (in a passage that Hill arbitrarily truncates), while we might be inclined to think these disparities in turnout don't matter so much, because age and education seem to be the most significant predictors of voting, rather than wealth or income directly, 'In so far as young people are born to young parents - which is particularly likely if they are relative uneducated and socio-economically deprived - young non-voters may, in fact, have young non-voting parents, family members and friends. In those circumstances, they may well lack anyone amongst those who vote who shares their interests and concerns'. (p.5)

So, I am not indifferent to problems of political inequality - whether manifested in disparities in electoral turnout or in other ways. However, what needs to be shown is why - of the many forms of inequality in our society - we should treat inequalities of turnout as so significant, or compulsory voting as so desirable, when what you can do with your vote depends fundamentally on the political choices you face (for example, who the parties and candidates are); what other voters are doing; and what scope for political action legislators face.

Put crudely, before forcing people to vote, because you are worried about them, you need to show that doing so will make a difference to their lives. But is voting in national elections more likely to improve the lot of the marginalised than participation in local politics or, perhaps, participation in anti-poverty movements, union drives, or in efforts to alter the behaviour of their local police, medical services, schools, churches or voluntary associations? Unless it is, why suppose that concern for their wellbeing requires them to vote; or requires other people to 
campaign in order to make abstention illegal? For myself, I simply cannot see how forcing persistent non-voters to vote will alter the entrenched inequalities of income and wealth in the UK until a majority of those who do habitually vote can be persuaded that redistributive politics are a legitimate, not an illegitimate, political goal and one that is realisable (albeit with help and coordination from the dreaded 'Europe').

Nor am I indifferent to problems of 'low turnout', despite Hill's claims to the contrary, although what counts as 'low turnout' is much more of a political matter than Hill seems willing to acknowledge. If $95 \%$ turnout is your standard, the rates of turnout in post-war Britain that now strike us as exemplary, might seem worryingly low. But it does not follow that this is how we should see them. Nor is it clear that the factors currently making for historically low turnouts in the UK are destined to stay that way, or to get worse unless we opt for compulsion. On the contrary, the huge dips in voting rates since the 1990s seem to reflect the collapse of the Conservatives as a successful opposition party until recently, and increasing voter disappointment, even disgust with, New Labour. So, whether $75 \%$ electoral turnout is 'high' or 'low' is hardly straightforward; nor is it clear whether we should expect turnout in the UK to fall much further, or to fall for much longer in future.

Forcing people to vote would, of course, increase turnout. What it would not do is make the UK's antiquated political and electoral system any more appealing to either voters or non-voters. The evidence suggests that compulsory voting does not increase people's interest or knowledge of politics; that it does not affect political outcomes; and the examples of Australia and Belgium hardly suggest that it does much for political equality or legitimacy, although Belgium recently announced that it would no longer fine or imprison those who fail to turn up to vote. ${ }^{5}$ Nor is that so

\footnotetext{
${ }^{5}$ See Chris Ballinger, 'Compulsory Turnout: A Solution to Disengagement?' in Democracy and Voting (The Hasard Soceity's Democracy7 Series, 2006), pp. 5 - 22; Jan Rovensky, 'Voting: A Citizen’s Right, or Duty? The Case Against Compulsory Voting', (doctoral dissertation, Faculty of Political Science, LUISS Guido Carli, Rome, 2007-08). Hill seems blithely indifferent to the problems generated by trying to institutionalise CV fairly. In Australia, the grounds on which conscientious exemptions will be granted are kept secret, presumably so that people do not use them to get round
} 
surprising. Paradoxical as it may seem, forcing everybody to vote is an apolitical way of addressing the very real conflicts of interest, desire and power which explain why so many people now find electoral and legislative politics alienating -even in countries whose political systems and egalitarian achievements social democrats in Britain often wish to emulate. ${ }^{6}$

Hill's belief that compulsory voting can be described as a 'benign coordinating mechanism' solving collective actions problems 'caused by informational uncertainty and maladaptive norms' says it all. On this picture, the reason why people don't vote is not that they cannot stand any of the political choices they face, do not believe that politicians will do - or can do - what they claim, and doubt that the choice of political party will fundamentally affect their lives, or the lives of people like them. No - for Hill, the problem is simply that rational voters will only vote if they know that others will also vote. So, rather than trying to persuade other people to vote with you - literally, not just metaphorically, by trying to take your friends, family, fellow-parents, workers or patients to the polls with you - she supposes that we should engage in a form of collective self-binding, so that we force our political opponents to vote in order to make sure that our political allies do too.

I may be missing something, but as an analysis of the causes of political alienation, and of its solutions, this is bizarre. However it illustrates, better than I ever could, a view of electoral democracy which assumes the death of constituency politics and of

either paying a fine for not-voting or being forced to vote. But that means that how exemptions are granted could be quite arbitrary, unfair and decided in ways that are paternalistic or authoritarian rather than democratic. Moreover, so I have been told by several Australians, middle-class people who don't want to vote simply pay the fine for not voting, which they treat as an annoying, if small, tax. In those circumstances it is premature to claim that compulsory voting promotes equality and/or legitimacy. For Belgium's recent announcement see, http://www.nrc.nl/buitenland/article2263399.ece/Belgie vervolgt niet-stemmers niet meer- . I owe the link to Dr. Alex Voorhoeve who, unlike me, can read Dutch.

${ }^{6}$ Proportional representation sometimes means that some small political parties are almost always part of a governing coalition, or that politics really is a matter of dividing the spoils amongst winners and losers. Moreover, as Bingham Powell has emphasised, pre-election coalitions rarely win outright majorities, and nor do single parties in majoritarian party systems. Far from majority government being the norm, then, Powell notes 'the persistent refusal of voters to deliver majority support for a single party or even a pre-election coalition'. This makes it likely that people's beliefs about the legitimacy of their government are more contingent and variable than we sometimes suppose. See, George Bingham Powell, Elections As Instruments of Democracy (Yale University Press) 2000, 129. See also Stein Ringen, 'The Message From Norway' in the Times Literary Supplement, February 13, 2004. 
local parties; that treats voting as essentially an individual act, rather than a fundamentally social and, often sociable, one; and therefore takes it for granted that political passion, camaraderie, and inventiveness cannot mobilise people-even if only to register a protest, show their defiance, or to indicate a desire, even a hope, for something better. British politics do not look rosy, but such a despairing picture seems premature, and at odds with successful efforts to mobilise voters in France and the USA, and even in the UK. We may not like the politics of some of the groups involved - but the ability of people like Shlafly or Le Pen to mobilise the alienated, the uninterested and the ignored deserves our attention and qualified respect no less than the efforts of Dean and Obama, or of Royal and Sarkozy.

I plead guilty, then, to the charge that I am uncertain about the importance of national elections to social democratic politics, both from a realistic and from an idealistic perspective. Realistically, I am keen for people to vote for social democratic parties or their nearest equivalent, but I am sceptical that electoral politics can do much in the absence of efforts to promote social democracy at work, in the administration of justice, welfare, healthcare, security or, indeed, in the family and in the international arena. So, how important electoral politics is relative to other forms of democratic politics (social movements, unions, pressure groups, NGOs, or more or less experimental and informal efforts to change our experiences of the arts, of education, of sport and so on) strikes me as an open - and partly empirical - question. $^{7}$

Uncertainty about the importance of electoral politics is reasonable and quite consistent with democratic commitments to treating people as free, equal and reasonable. It is quite unlike uncertainty about whether honour killing is wrong (or the conviction that it is right), though Hill claims to see no difference between them. The London Review of Books recently had a lengthy review by Jacqueline Rose on the subject of honour killings and women's efforts to publicise the nature and extent of the evil, and to hold both its perpetrators and complacent religious and civil

\footnotetext{
${ }^{7}$ Of course, a great deal turns on how we specify the relevant counter-factuals, and that is why reasonable disagreement on the matter is so common, and why the issue is not simply empirical.
} 
authorities to account for their actions and inactions. ${ }^{8}$ But it should take no great knowledge to see that honour killings are inconsistent with a democratic view of the rights and status of women, and with democratic forms of freedom and equality (not least, freedom of association between the sexes and across religions and nationalities). So, while democratic states are certainly justified in condemning honour killings, we still need an explanation for why, given reasonable doubts about the relative benefits and importance of electoral politics in democracies, we should make the failure to vote illegal and punishable by law. ${ }^{9}$

But what troubles me about arguments for compulsory voting is not just their interpretation of political reality (though I appreciate Hill's recognition that nonvoters cannot be understood as free-riders, with its implication that racist voters are morally superior to alienated nonvoters), but their view of the desirable or ideal. I cannot understand what is so desirable about high electoral turnout (however defined), or even equal turnout (whether with high or low turnout), if people are contemptuous of their leaders, uninterested in politics, naïve or unsophisticated in their views, or manipulated by the latest tabloid campaign or media 'scare'. If the point of democratic government, as I suppose, is to reflect people's interests in selfgovernment, then the quality of political participation is at least as important as its quantity, and the importance of the latter probably derives from the significance of the former. ${ }^{10}$

Above all, the reasons to consider Schumpeter's 'elitist' model of politics an inadequate view of democracy strike me as reasons to lament a conception of politics which fixes our attention on rates of turnout in the choice of leaders, but

\footnotetext{
${ }^{8}$ Jacqueline Rose, 'A Piece of White Silk' London Review of Books (Vol. 31, No. 21, 5 Nov. 2009), pp. $5-8$.

${ }_{9}$ I discuss the difficulty with the alleged similarities between compulsory voting, jury service and military service in 'Is Compulsory Voting Justified?' Public Reason (Vol. 1, Issue 1) 2009, pp. 57-74, at pp. 70-71. This can be found online without charge at http://www.publicreason/home.

${ }^{10}$ By quality, I mean the informational basis and motivations on which people vote, the range of choices which they face, and the character or ethos with which the election is fought. Quantity understood either as number of elections, or numbers who vote in an election - is important only so far as it tells us something about the quality of the election: people's ability to influence political outcomes via their choice of representatives. In the absence of reasons to think that electoral choices are sufficiently wide, that the electorate is adequately informed, that politicians are reasonably truthful and honest, it is hard to see why increases of quantity should be desirable.
} 
shows no interest in the ability of ordinary people to become political leaders

themselves. After all, in the UK at least, the precipitous decline in voting rates since

the 1990s parallels the near collapse of routes for working class people to gain entry

into national politics, let alone to attain positions of leadership and public

responsibility in their parties.

Democracy is not simply about electing leaders. It is also about the ability of

ordinary people to become leaders, and to hold positions of power and responsibility in their society. Perhaps if we took more seriously the rights and duties of ordinary people as leaders or potential leaders - trying to clarify what these are and what they imply for public policy - we could improve contemporary political theory and practice, and make both more appealing and accessible in the process. ${ }^{11}$

\footnotetext{
${ }^{11}$ The Feminist movement in the USA and UK suggest that this is possible. Until women came to see themselves as political agents, even as leaders, rather than followers or helpers, many of them weren't particularly interested in politics, or particularly keen to vote. It is probably not unusual that people who feel that they are political outsiders come to electoral politics as a consequence of politicisation in some other area or field (union politics, welfare politics, sexual politics etc) rather than the other way round. If that's so, then Lijphart may be mistaken to believe that voting is the 'low cost' route into democratic politics for the poor or marginalised, as compared to other forms of politics which may be more costly in terms of time or money. Cost being relative to benefit, it is possible that the latter are actually 'cheaper' than the former. Trying to cast an effective vote requires time and attention, and may be quite dull and frustrating. By contrast, less formal types of political activity may offer companionship, fun and a sense of self-worth and agency, whether or not they prove successful in instrumental terms.
} 